\title{
Synthesis and Characterizations of Hydroxyapatite from Bovine Bone Using Alkaline Hydrolysis Method
}

\author{
Nuning Aisah ${ }^{1, *}$, Muslim Efendi Harahap ${ }^{1}$, Dwi Budianto ${ }^{1}$, Mirza Wibowo ${ }^{1}$, Mohammad Dachyar Effendi ${ }^{1}$, \\ Jan Setiawan ${ }^{2}$, Seto Roseno ${ }^{1}$, Dwi Gustiono ${ }^{1}$
}

\begin{abstract}
In this research, the synthesis of hydroxyapatite compound (HAp) has been done by extracting technique from cow cortex thigh bones to eliminate organic compounds contained in bone so that it can be used as raw material of bone graft. The method used is alkaline hydrolysis method of soaking bone in $\mathrm{NaOH}$ solution with variation of concentration $(1 \mathrm{M}, 2 \mathrm{M}, 3 \mathrm{M})$ and immersion time ( 30 minutes, 60 minutes, 90 minutes). The extracted HAp powder was then analyzed using FTIR, XRD and SEM. The results showed that a hydroxyapatite powder with a soaking time of 30 minutes and a $2 \mathrm{M}$ and $3 \mathrm{M} \mathrm{NaOH}$ concentration did not contain organic elements. The XRD peak pattern shows the phase formed is a hydroxyapatite with a hexagonal structure having an average crystal size of 10-12 nm.
\end{abstract}

Keywords - hydroxyapatite, cortex, extraction, hydrolysis

\section{INTRODUCTION}

$\mathbf{N}$ EEDS of biomaterials in Indonesia continue to increase, especially the need for biomaterials as bone graft materials for the implantation process. Bone graft is a bone that is transplanted from one area to another to help healing, strengthening, and repairing functions. The bone graft based on its sources can be grouped into four, i.e., Autograft when it comes from their own individual bone, Allograft when it comes from the bones of other individuals of the same species, Xenograft when it is derived from different species, and Synthetic graft when it is derived from artificial or synthetic materials [1]. Currently there has been much development of raw materials for biomaterials for bone graft replacement, such as utilization of fish bone waste [2, 3], cow thigh bone waste [4] and green shells waste [5].

The most commonly used raw material for biomaterial for biomedical applications is hydroxyapatite. Hydroxyapatite (HAp) or calcium hydroxyapatite is a type of apatite material $\left[\mathrm{M}_{10}\left(\mathrm{XO}_{4}\right)_{6} \mathrm{Z}_{2}\right]$ with a chemical formula $\mathrm{Ca}_{10}\left(\mathrm{PO}_{4}\right)_{6} \mathrm{OH}_{2}$ often applied in the medical and dental fields [6]. Hydroxyapatite production is currently dominated by products from Japan and South Korea, hence to meet the needs of its hydroxyapatite Indonesia still relies on imported materials. Consequently, the price of hydroxyapatite in Indonesia is expensive (high price).

To be used as a bone graft feedstock, hydroxyapatite not only has a biocompatible, osteoconductive, non-toxic, and non-immunological but also it has bioactive properties [6]. The bioactive of hydroxyapatite can coalesce with human bones by forming a layer of biological apatite to form a direct chemical bond with bone. Biocompatible hydroxyapatite can adapt to the human body and does not cause immunology, i.e. the rejection reaction of the human immune system, whereas osteoconductive hydroxyapatite can stimulate bone formation and growth [7].
Cow is one of the most consumed livestock by the people of Indonesia. The need for beef continues to increase every year, therefore the requirement of beef cattle in Indonesia in the last five years (2011-2015) increased almost twice from the previous year population (Agricultural Information Center and Information System of the Secretariat General of the Ministry of Agriculture, 2015). Almost all parts of the cow can be utilized for human needs, such as meat for food material, milk for drinks, leather for handicraft raw materials. However, the utilization of cow bone waste is still considered less, whereas in the bones of cows contain minerals apatite that can be used for raw materials bone graft.

Hydroxyapatite can be extracted from cow thigh bone by using several methods, namely, hydrothermal method [7], precipitation [6], spray drying [8], and alkaline hydrolysis [4]. The extraction process aims to remove organic substances contained in the bone such as protein and fat, in which bones contain as much as 65\% - 70\% hydroxyapatite and 30\% $35 \%$ organic matter (in wet weight conditions) [9]. Researches related to the extraction of hydroxyapatite from cow bone that have been done, among others were by Aida who extracted hydroxyapatite from cow bone by using combination method of ultrasonic and spray drying [8], Hilmi by doing hydroxyapatite extraction from cow bone with calcination method and producing crystalline hydroxyapatite [7].

This research used strong alkaline hydrolysis method with variation of concentration and time of bone immersion. The bone used is the cow thigh bone of the cortex where the bone of the cortex is a solid bone containing many minerals.

\section{RESEARCH METHOD}

\section{A. Preparation of Bone Samples}

The cortex part of thigh cow bone was taken and removed its cancellous part, then cut the cortex to the size of $1 \times 2 \mathrm{~cm}$. The bones are then washed thoroughly with water to remove any bone marrow, meat, and debris remnants.

\section{B. Fat Removal}

The bone was soaked for 1 hour in a methanol-chloroform solution of 1: 1 ratio, then washed for 6 hours. Then it was boiled in distilled water for 5 hours and cooked with high pressure for 3 hours to remove the fat that is still attached to the bone.

\section{Protein Removal}

The process of protein removal or deproteinization was done by soaking the bone in the $\mathrm{NaOH}$ solution. A total of 10 grams of bone were immersed in $\mathrm{NaOH}$ solution with 
variation of solution concentration i.e. $1 \mathrm{M}, 2 \mathrm{M}$ and $3 \mathrm{M}$. The duration of immersion time for each sample was 30 minutes, 60 minutes and 90 minutes. Immersion is carried out in the autoclave at a temperature of $121^{\circ} \mathrm{C}$ at $1.5 \mathrm{~atm}$ pressure. Then the sample was neutralized as much as 4-7 times using distilled water to reach $\mathrm{pH} 7$, then it was filtered using Buchner.

\section{Bone Powder Making}

The cow thigh bone which had been deproteinized was dried in an oven at $80{ }^{\circ} \mathrm{C}$ for 24 hours to remove the water content still present in the bone. Then the dried bone was crushed with mortar to form powder.

\section{E. Characterization of Bone Powder}

To know the characteristics of functional group of hydroxyapatite which have been formed from cow thigh bone extraction, it was used Fourier Transform Infra Red (FTIR: Nicolet iS50 FT-IR) test, measured at wave numbers 4000 400. Characteristics of the crystal system were analyzed through X-Ray Diffraction (XRD: Rigaku $C u K_{a}$ ). While the sample morphological evaluation is performed using Scanning Electron Microscope (SEM: Hitachi SU3500).

\section{RESULTS AND DISCUSSION}

\section{A. Loss of Bone Weight After Immersion}

Hydroxyapatite extraction aims to remove organic compounds contained in the bone, such as proteins and fats, to obtain inorganic compounds of apatite mineral. Loss of cow thigh cortex bone after the extraction process with variations of Sodium Hydroxide concentration $1 \mathrm{M}, 2 \mathrm{M}$ and $3 \mathrm{M}$ for duration of 30 minutes, 60 minutes and 90 minutes respectively can be seen in the Fig. 1.

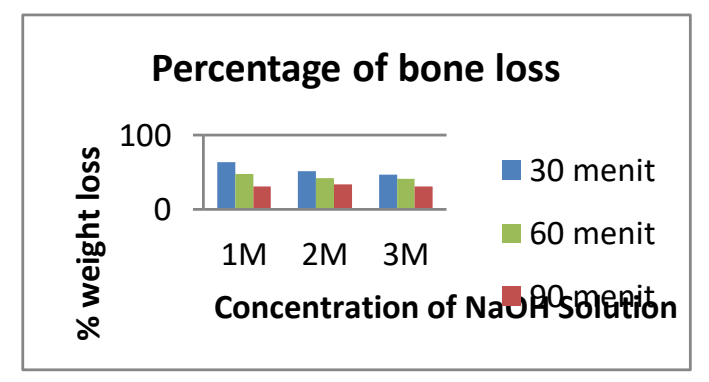

Fig. 1. Percentage of bone weight loss after immersion

Based on the Fig. 1, it can be seen that the largest loss of bone weight is at the 30 minute immersion time, with average $54,02978 \%$. While at the 60 and 90 minute immersion time, the average percentage of loss of bone weight are $43,70607 \%$ and $31,61263 \%$. The results show that the longer time bone soaking will be the less weight lost. The amount of lost bone weight shows the amount of organic matter lost.

\section{B. Characterization fo Functional Group with FTIR}

The FTIR spectrum aims to provide information on the functional groups present in soaking cow bone powder. Functional groups found in soaking cow bone powder with $\mathrm{NaOH}$ concentrations of $1 \mathrm{M}, 2 \mathrm{M}$, and $3 \mathrm{M}$ respectively for 30 minutes, 60 minutes, and 90 minutes can be seen in Fig. 2. It can be seen that in all samples there are relatively similar functional groups, i.e. the hydroxide $(\mathrm{OH})$, phosphate $\left(\mathrm{PO}_{4}\right)$, and carbonate $\left(\mathrm{CO}_{3}\right)$ groups which are inorganic substances of the cow bone powder [8].

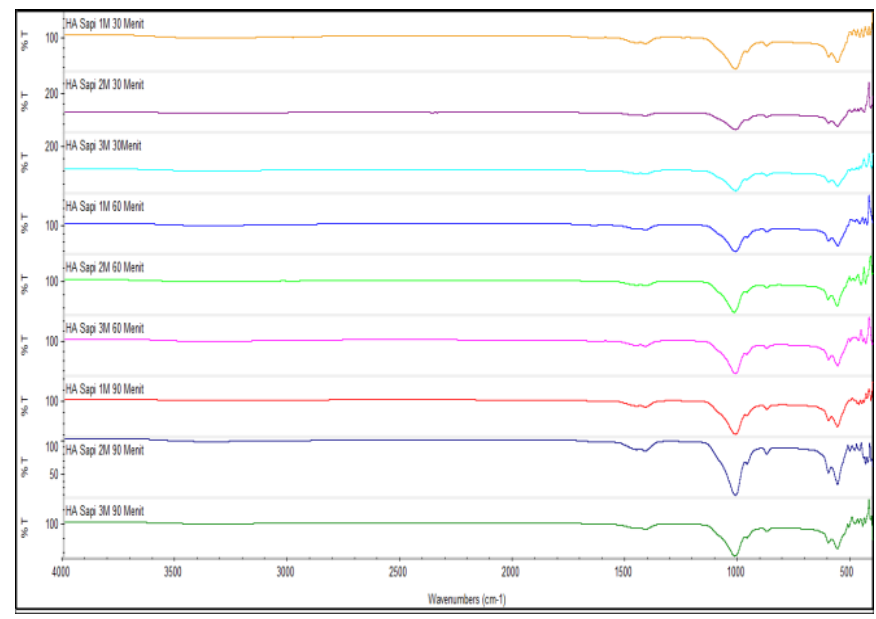

Fig. 2. FTIR spectrum for cow bone powder

In the FTIR test results there is also a typical uptake of carbonate $\left(\mathrm{CO}_{3}\right)^{2-}$ that is bending vibration $\mathrm{C}-\mathrm{O}$ at wave numbers $873.29 ; 873.21 ; 873.35 ; 873.48 ; 873.23 ; 873,34$; 873.49. Then there is also phosphate $\left(\mathrm{PO}_{4}\right)^{3-}$ uptake which is asymmetric bending vibration $\mathrm{P}-\mathrm{O}$ at wave numbers 558,$23 ; 558.48 ; 560,32 ; 558.46 ; 559.22 ; 558.98 ; 559,51$. The hydroxyapatite type formed is hydroxyapatite carbonate. The carbonate element is usually formed on hydroxyapatites derived from biological sources [2]. The carbonate element present in the hydroxyapatite shows that the compound has good bioactive properties [6].

In the cow bone powder with soaking treatment for 30 minutes in $\mathrm{NaOH}$ solution of concentration $1 \mathrm{M}$ and $2 \mathrm{M}$ is still found a slightly different spectrum of FTIR test result that is the emergence of wave numbers $2980,06 \mathrm{~cm}^{-1}$ and $2360,44 \mathrm{~cm}^{-1}$ as shown in Fig. 3. This indicates the existence of organic substance in bone powder that can cause rejection reactions when implanted in the human body.

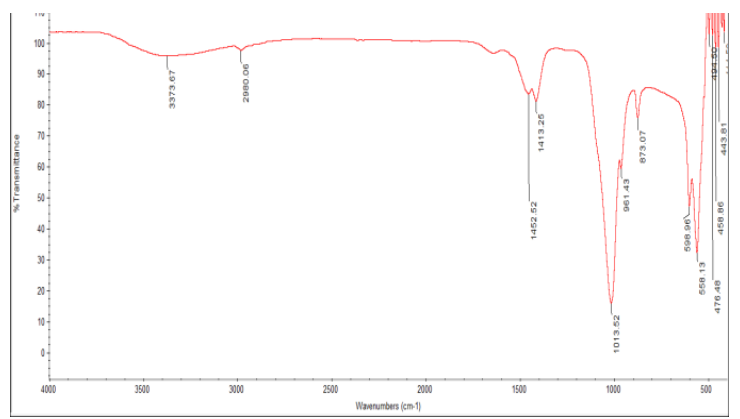




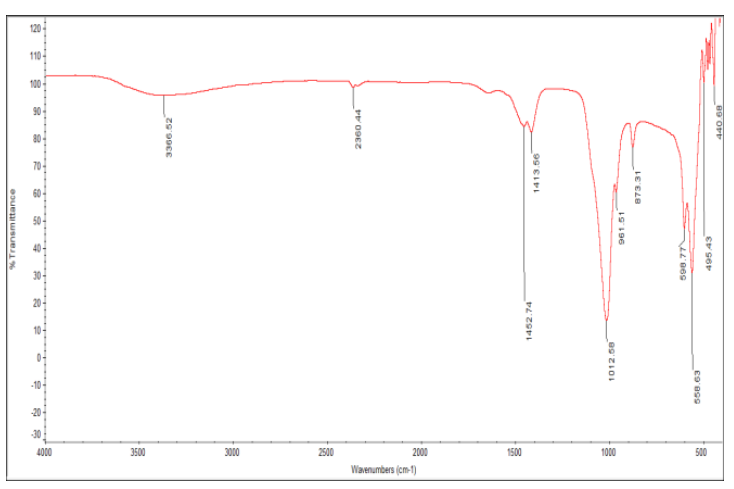

Fig. 3. FTIR spectrum for cow bone powder with soaking treatment in $\mathrm{NaOH}$ Solution $1 \mathrm{M}$ and $2 \mathrm{M}$ for 30 minutes

\section{Characterization of Morphology with SEM-EDX}

Bovine bone powder (apatite) as result of this extraction is generally not to smooth so that the morphological observations with SEM are less clear.
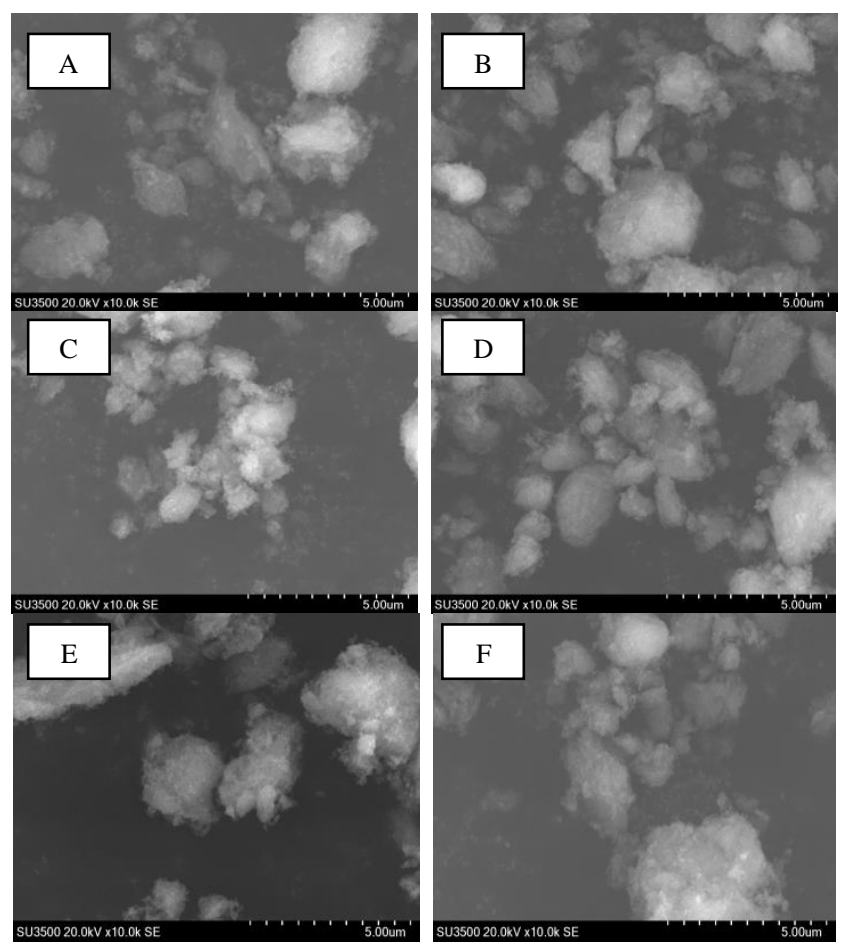

Fig. 4. Microstructure of cow bone powder with magnification $10000 \mathrm{x}$ $\mathrm{A}\left(1 \mathrm{M}, 30^{\prime}\right)$; B(1M,90'); C(2M,30'): D(2M,90'): E(3M,30'): F(3M,90')

As for the analysis of the distribution of powder forming elements can be seen from Fig. 5. From the spectra it is obtained that the ratio of $\mathrm{Ca} / \mathrm{P}$ powder produced is $1.965 \%$ wt or about $1.519 \%$ of atoms.

\section{Published online: 20/04/2018}
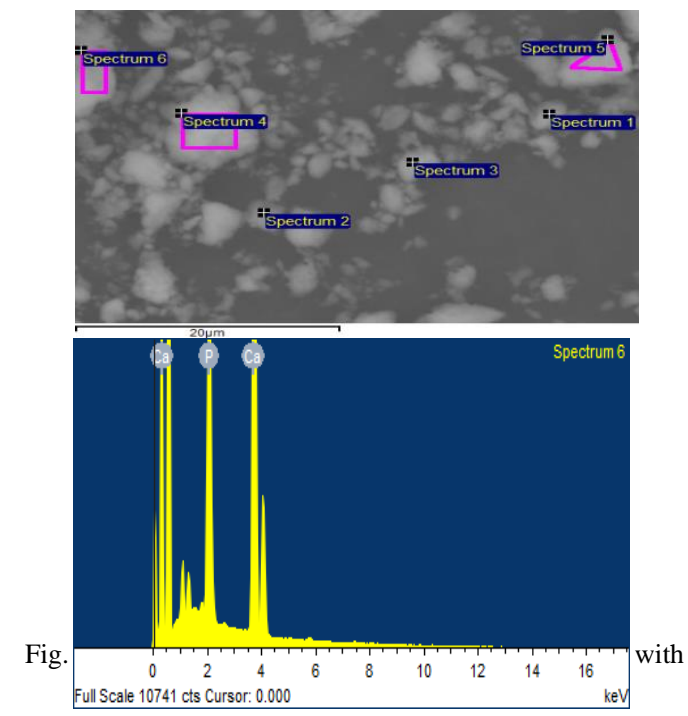

D. Characterization of Crystal Structures with XRD

XRD spectrum pattern curve for apatite powder with 30 minute immersion time can be seen in Fig. 6 below,

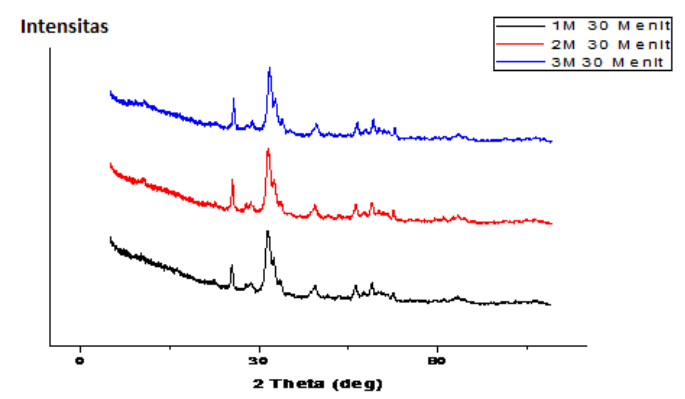

Fig. 6. Pattern of apatite powder diffraction with $\mathrm{t}=30$ minutes

The compound formed from cow bone extraction is Calcium Hydroxide Phosphate with chemical formula $\mathrm{Ca}_{10}\left(\mathrm{PO}_{4}\right)_{6}(\mathrm{OH})_{2}$. From the comparison of XRD graph with time immersion period of 30 minutes of $1 \mathrm{M}, 2 \mathrm{M}$, and $3 \mathrm{M}$ concentration, it was found that there was no phase change from the hydroxyapatite powder produced from cow bone extraction. The resulting hydroxyapatite data match with the International Center for Diffraction Database (ICDD) data with card number 01-074-0566. The highest peak is in field 121 for all samples. Similarly for 60 and 90 minutes soaking time as shown in Fig. 7 below. 


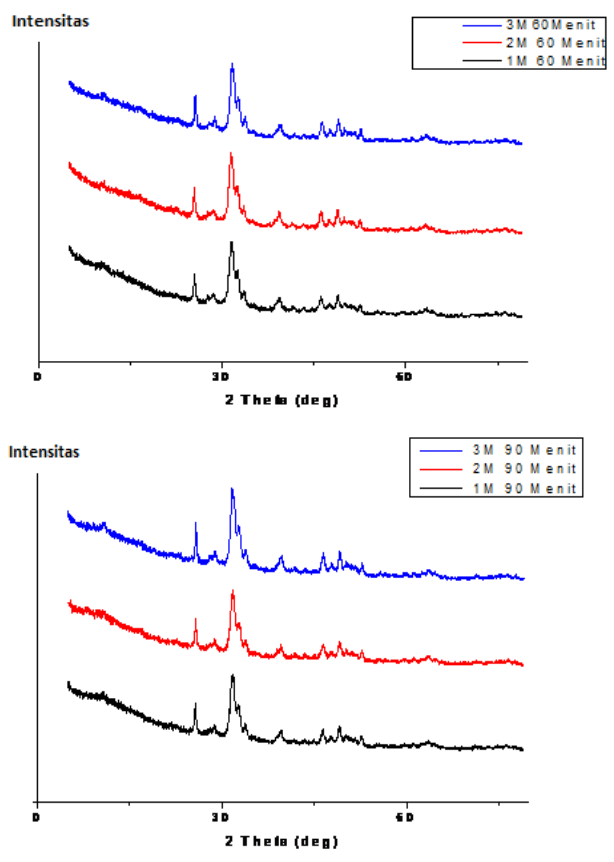

Fig. 7. Bone powder diffraction pattern with immersion 60 and 90 minutes

The standard lattice parameters of a hydroxyapatite powder are $\mathrm{a}=\mathrm{b}=9,42 \AA$ and $\mathrm{c}=6.88 \AA$. The lattice parameter values for the three samples were close to the standard lattice parameter values, where in the analysis results obtained lattice parameter values for $1 \mathrm{M}$ concentrations i.e., a and $\mathrm{b}$ of $9,418 \AA$ and $\mathrm{c}$ of $6,880 \AA$. For the $2 \mathrm{M}$ concentration, the values of $\mathrm{a}$ and $\mathrm{b}$ are $9,407 \AA$ and the value of $\mathrm{c}$ is $6,870 \AA$. For $3 \mathrm{M}$ concentrations, the values of $\mathrm{a}$ and $\mathrm{b}$ are $9,433 \AA$ and the value of $\mathrm{c}$ is $6,880 \AA$. The value of the lattice parameter where the value of $a=b \neq c$ indicates the crystal structure formed is hexagonal. The intensity value increases with the added concentration of Sodium Hydroxide solution used. The largest crystal size was found in the $3 \mathrm{M}$ concentration sample of $12.1276 \mathrm{~nm}$, where the larger the size of the crystal the better the degree of crystallinity of hydroxyapatite. It is reinforced in the previous study that obtained crystal size about $13 \mathrm{~nm}$ [4], so that the recent results of the present study can be said successfully to reduce the size of the crystals of hydroxyapatite powder.

\section{CONCLUSION}

This research has succeeded in extraction of hydroxyapatite compound from bovine thigh cortex bone with alkaline hydrolysis method with Sodium Hydroxide solution. The type of hydroxyapatite formed is a hydroxyapatite of carbonate in which the carbonate element is commonly formed on hydroxyapatite derived from a biological source. The XRD peak pattern shows the phase formed is a hydroxyapatite with a hexagonal structure having an average crystal size of 10-12 nm.

\section{ACKNOWLEDGMENT}

Thanks to DIPA-BPPT Program, PTSM BATAN and PUSLIT Fisika LIPI for the supports and facilities provided.

\section{REFERENCES}

[1] M. Z. Ichsan, "Sintesis makroporus komposit kolagen-hidroksiapatit sebagai kandidat bone graft," Universitas Airlangga, Surabaya, 2012.

[2] B. Riyanto, A. Maddu \& Nurrahman, "Material biokeramik berbasis hidroksiapatit tulang ikan tuna," JPHPI, vol 16 nomor 2, pp. 119-132, 2013.

[3] W. Trilaksani, E. Salamah \& M. Nabil, "Pemanfaatan limbah tulang ikan tuna sebagai sumber kalsium dengan metode hidrolisis protein," Buletin Teknologi Hasil Perikanan, vol IX nomor 2, 2006.

[4] W. Sokowati, "Isolasi dan karakterisasi senyawa hidroksiapatit dari tulang korteks sapi (bos taurus)," Universitas Pancasila, Jakarta, 2014.

[5] Sugandi, et.al, " Pemanfaatan cangkang kerang hijau (Pernia viridis L.) sebagai bone subsitute berporogen selulosa nata de coco," Institut Pertanian Bogor, Bogor, 2014.

[6] B.P. Purwasasmita, R.S. Gultom, " Sintesis dan karakterisasi serbuk hidroksiapatit skala sub-mikron menggunakan metode presipitasi," Jurnal Bionatura, vol 10 nomor 2, pp. 158-167, 2008.

[7] I. Hilmi, M. Rinastiti \& M. K. Herliansyah, "Synthesis of hydoxyapatite from local bovine bones for biomedical application" Proceeding of International Conference on Instrumentation, Communication, Information Technology and Biomedical Engineering, Bandung, 2011.

[8] A. R. Pudjiastuti, "Preparasi hidroksiapatit dari tulang sapi dengan metode kombinasi ultrasonik dan spray drying," Universitas Indonesia Depok, 2014.

[9] N. A. M. Barakat, et al, "Extraction of pure natural hydoxyapatite from the bovine bones bio waste by three different methods," J. of Materials Processing Technology, vol 209, pp. 3408-3415, 2009. 